\title{
IMPLEMENTATION OF TRIPLE HELIX MODEL ON THE DEVELOPMENTOF YOUNG ENTREPRENEURS
}

\author{
AUTHOR \\ Moh. Agung Surianto', Umaimah ${ }^{2}$ \\ Management Program, Universitas Muhammadiyah Gresik ${ }^{1}$ \\ Accounting Department, Universitas Muhammadiyah Gresik ${ }^{2}$ \\ cakagung@umg.ac.id ${ }^{1}$, umaimah@umg.ac.id ${ }^{2}$
}

\begin{abstract}
This study aims to examine the implementation of the Triple Helix model in the development of youth entrepreneurship in Gresik Regency. This research approach uses descriptive qualitative, by starting to identify the increasing open unemployment in Gresik Regency in 2018 when compared to the previous year. Data collection methods used are by way of, indept interview, and documentation. Data analysis techniques using the Triple Helix Etzkowitz \& Leydesdorff approach. The results showed that there was no implementation of the Triple Helixmodel to develop youth entrepreneurship in Gresik Regency, but with the potential that exists, in the future it is possible to open opportunities to implement the Triple Helix Etzkowitz \& Leydesdorff model in Gresik Regency.
\end{abstract}

Keywords: Triple Helix Model, Entrepreneurship Development, youth

\section{INTRODUCTION}

The Minister of Manpower of the Republic of Indonesia stated that the impact of the Covid Pandemic 19 caused an increase in unemployment to increase by around 2.92 million

5.23 million, and is even expected to reach double digits by the end of 2020 ( https://money.kompas.com/ : July 1 2020). This figure adds to the data from the Central Statistics Agency (BPS) previously which recorded the number of open unemployment in Indonesia in August 2019 amounting to 7.05 million people, an increase from August 2018 which was only 7 million people.

The level of open unemployment (TPT) is dominated by Vocational High School (SMK) graduates by $10.42 \%$. SMA was ranked second with a percentage of $7.92 \%$, followed by diploma I / II / III 5.99 \% , universities $5.67 \%$. In line with national data (in Indonesia), openunemployment in Gresik Regency is also dominated by young people as much as 38,681 peopleor around $5.82 \%$ of the total workforce of 664,523 people.

The unemployment rate experienced to ride an approximately $28.5 \%$ if dibandi ng kanwith unemployment data earlier in 2017 that as many as 30089 people. Of course the increasein open unemployment mentioned above needs to be a joint concern of stakeholders 
in GresikRegency. The irony of the increase in the number of unemployed data with the character of theGresik region as an industrial area is the basis of current research. In addition to theresponsibility of government, universities and companies need to be involved to implement themodel T riple $H$ Elix as developed Etzkowitz \& Leydesdorff 1995 on pe entrepreneurial development of young in Gresik.

The results of research of conducted by Nurzal and Waluyo (2012) entitled; The Triple Helix Model in Developing Technological Innovation The Case of Computer Based Interlocking shows that the development model of computer based interlocking technology innovation (CBI) as the "brain" in controlling electric train lines using the Triple helix approachrequires innovation as well as the support of three pillars, universities, government and industry. The role of government is vital in supporting the innovation ecosystem, with the support of industry and the university's research and development team. Three pillars in the Triple Helix concept are needed in forming a consortium to develop research that consists of acomposition of government, industry and university representatives.

The results of Cai's (2014) study entitled: Implementing the Triple Helix model in a nonWestern context: an institutional logics perspective. Cai's research conducted in China provides a different perspective of results from the Triple Helix concept developed by Etzkowitz \& Leydesdorff. Cai stated that there is a general belief among policy makers and academics around the world that the Triple Helix relationship between universities, industry and government provides optimal conditions for innovation. But there are important things to note that the Triple Helix concept was developed from the economic experience of developed countries in the West.

Cai (2014) states that there is a need to consider theoretically and empirical evidence about whether the Triple Helix model can be applied in non-Western contexts such as in China. Following the understanding that the ideal evolution of the Triple Helix model was facilitated by certain institutional logics in Western society, the State of China has an institutional logic in China that is different from that in the West. More Cai stated that research had shown that in order to optimize the innovation policy in the country of China, is necessary to adjust some environmental elements institutional to facilitate interaction between actors major innovations and on the other side to be innovative in developing mode 1 Triple Helix, given the institutional environment of China is unique and will survive in the future.

The results of another study conducted by Pique, et al (2018) entitled: Triple Helix and The Evolution of Ecosystems of Innovation: The Case of Silicon Valey, shows that the role ofTriple Helix agents is always evolving over time, as is the case with the demands of the innovation ecosystem. The main changes refer to (1) the rise of accelerator programs as new players in the ecosystem; (2) company involvement with startups; (3) the geographical expansion of Silicon Valley, including San Francisco; (4) increasing university commitment tofunding capital; and (5) the rise of multinational companies due to lack of talent and intense competition in the Silicon Valey region.

From some of the previous research results above show that the implementation of the 
Triple Helix model as developed by Etzkowitz \& Leydesdorff in 1995, is not absolutely the same between regions or countries. The characteristics of western countries that are more pro-market will be different in countries where the economic system is more dominantly controlledby the government in its economic activities. A different approach is needed in implementing the Triple Helix model as developed by Etzkowitz \& Leydesdorff . The current study aimsm erumuskan youth entrepreneurship development model in Gresik to approach T riple H Elix Etzkowitz \& Leydesdorff.

\section{METHODS}

This study uses a descriptive qualitative approach, namely research that seeks to describe the facts as they are and is then analyzed and concluded about these facts. The location of this research is in Gresik Regency, East Java. Current research is limited to the Triple Helix implementation study with the three element approach; universities, government and companies in Gresik Regency. The informants in this study were from the elements of young people, elements of company representatives and government officials in Gresik Regency.

The type of data used in this study are primary data and secondary data. Secondary datawere obtained from BPS Regency of Gresik, an exploratory study of journals and mass medianews. While the primary data obtained from the surveys, interviews and documentation of stakeholders is important in the strategy of the development of youth entrepreneurship modelof youth entrepreneurship development model in Gresik to approach T riple H Elix Etzkowitz\& Leydesdorff

\section{RESULT AND DISCUSSION}

The informants who were the interviewees for in-depth interviews in collecting data are as the following table;

Table 3: Profile of Research Informants

\begin{tabular}{lll}
\hline No & \multicolumn{1}{c}{ Name } & \multicolumn{1}{c}{ Profession } \\
\hline 1 & Alfida & College student \\
2 & Edy Saraya & GM of Semen Indonesia CSR \\
3 & Umaimah & Univ. Lecturer Muhammadiyah Gresik \\
4 & Samsul Arifin & Gresik Regency Manpower Office
\end{tabular}

Source: Primary Data Processed: June-July 2020

Geographically Gresik strongly supports the climate of entrepreneurship development of youth is ;

\section{a) High Population and Purchasing Power}

The population of Gresik which has reached 1299769 inhabitants (Gresik In 
Numbers:2019) and the level of the minimum wage each year Gresik which is ranked second after the city of Surabaya in East Java is a supporting factor conducive to entrepreneurial activity. As an illustration, the minimum wage in Gresik in 2019 is Rp. 3,867,874 ( East Java Governor Regulation Number 188 of 2018) ranks second highest in East Java. If one company has 500employees, the velocity of money in one company each month reaches more than Rp. 1.5 billion While the company data that has been registered with TDI in the Gresik Government for the period 2003-2013 is 675 ( http://gresikkab.go.id/:2014 ).

b) The industrialization process is continuing quickly

Referring Plan of Spatial Planning (RTRW) Gresik In 2010-2030, nearly a third of the district of Gresik is a coastal area, which is along the $140 \mathrm{Km}$ covering Sub Kebomas, Gresik,Manyar, Bungah, Sidayu, Ujungpangkah, and Panceng and the District Fishponds and Sangkapura located on Bawean Island. In the coastal area of Gresik Regency, it has been facilitated by public ports and special ports / docks, so that Gresik Regency has regional and national trade access. This geographical advantage makes Gresik the best alternative for investment or investment.

The construction of the Java Integrated Industrial and Port Estate (JIIPE) International Port in Kalimireng Manyar, Gresik Regency, which began in 2013 and has completed the first phase in 2015 (http://bisnis.liputan6.com: 31 January 2016) will have amultiplier effect high with the increasing number of industries that will stand in Gresik as wellas housing needs and other basic needs

c) There are many corporate social responsibility programs ( Corporate Social Responsibility )

Based on Article 74 of RI Law No. 40 of 2007 concerning Limited Liability Companies(PT) confirms that every company that carries on its business activities in and related to natura

resources is required to carry out social and environmental responsibilities . In 2015, the GresikDistrict Government received total Corporate Social Responsibility (CSR) funds in the amountof Rp. 40 billion ( http://gresikkab.go.id/: November 16, 2015 ). There are at least three (3) SOEs that have a head office in Gresik; PT. Petrokimia Gresik, PT. Semen Indonesia and PT. Java \& Bali Power Plant (PJB) as well as hundreds of regional and national private companies operating in the Gresik region.

\section{d) Entrepreneurship Program from the Gresik Regency Government}

By periodically, Gresik regency government implemented development programs foryouth entrepreneurship. The Gresik Regency Manpower Office becomes one of the spearheadsof the entrepreneurship program by presenting speakers from business and universities.

Samsul Arifin, one of the heads of work placement and expansion in Gresik Regency,stated that the past five years the youth entrepreneurship development program has been carriedout by the Gresik Regency Manpower Office. In 2020, due to the impact 
of the Covid 19 pandemic, there was a budget refocussing on the handling of Covid 19, so there was no entrepreneurial program. But in 2020, Samsul ensured that the entrepreneurship development program will return, and open a partnership with Muhammaduyah University Gresik.

\section{e) Entrepreneurship Program from Higher Education Institutions (Universities)}

One of the biggest universities in Gresik is Muhammadiyah UniversityGresik. Umaimah, one of the lecturers at the University, stated that almost every year the university carries out entrepreneurship programs. In 2019, the university has collaborated withthe CSR of Semen Indonesia. In 2020, there will be a plan for further collaboration programs.Umaimah further stated that the program that had tri-party synergy (as the Triple Helix Concept) involving universities, government and companies had not yet been implemented. Sofar, only two parties have been running; university with government or university with company.
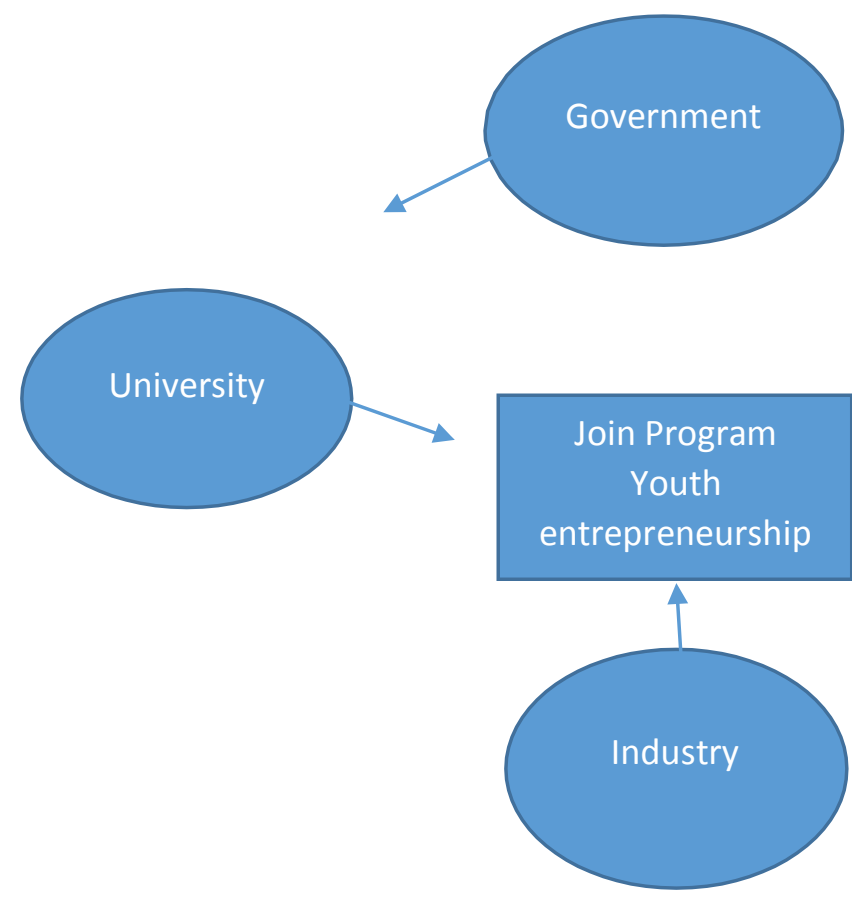

Figure 1. Triple Helix Model in the development of Youth Entrepreneurship in Gresik Regency

\section{CONCLUSION}

\section{a) Conclusion}

1) Until the time of this research, there has been no implementation of the Triple Helix modelto develop youth entrepreneurship in Gresik Regency.

2) The existing entrepreneurship development model is limited to the cooperation 
of twoparties; universities with the government or universities with companies.

3) With the existing potential, in the future it is possible to open opportunities to implement theTriple Helix Etzkowitz \& Leydesdorff model in Gresik Regency.

\section{b) Suggestion}

suggestion could in convey in this study are:

1) Need to build better cooperation in order to develop the implementation of the Triple Helixmodel as developed by Etzkowitz \& Leydesdorff in Gresik Regency.

2) The internal policy constraints of each organization which so far only work partially can be developed with tri-partite collaboration as the Etzkowitz \& Leydesdorff model in Gresik Regency.

\section{References}

Badan Pusat Statistik Kabupaten Gresik. 2019. Kabupaten Gresik Dalam Angka: 2019.

Cai Yuzhuo, 2014. Implementing the Triple Helix model in a non-Western context: an institutional logics perspective. http://link.springer.com/article/10.1186/s40604-014$\underline{0001-2}$

https://money.kompas.com/: 1 Juli 2020, Tiga Jurus Menaker Tekan Pengangguran Akibat Pandemi. Tanggal akses 2 Juli 2020.

Marwanti, Sri dan Astuti, Ismi Dwi: 2012. Model Pemberdayaan Perempuan Miskin Melalui Pengembangan Kewirausahaan Keluarga Menuju Ekonomi Kreatif Di Kabupaten Karanganyar: Sepa: Vol 9 No.1 September 2012: 134-144:ISSN: 1829-9946.

Mudjiarto dan Wahid Aliaras: 2006: Membangun Karakter dan Kepribadian Kewirausahaan: Graha Ilmu: Yogyakarta\& UIEU: Jakarta

Nurzal Erry Ricardo, Waluyo Marhaindro, 2012. Triple Helix Model in Developing Technological Innovation: The Case of Computer Based Interlocking. The Asian Journal of Technology Management Vol. 5 No. 2 (2012): 53-58.

Peraturan Gubernur Jatim Nomor 188 Tahun 2018. Upah Minimum Kabupaten dan Kota di Jawa Timur. Tanggal akses 1 Juli 2020

Pique Josep M, Mirabent Jasmina Berbegel, Etzkowitz Henry, 2018. Triple Helix and the evolution of ecosystems of innovation: the case of Silicon Valley. http://creativecommons.org/licenses/by/4.0 